\title{
OPEN Resistance status of lepidopteran soybean pests following large-scale use of MON $87701 \times$ MON 89788 soybean in Brazil
}

Renato J. Horikoshi ${ }^{1 凶}$, Oderlei Bernardi ${ }^{2}$, Daniela N. Godoy ${ }^{2}$, Altair A. Semeão ${ }^{1}$, Alan Willse ${ }^{3}$, Gustavo O. Corazza ${ }^{1}$, Elderson Ruthes ${ }^{4}$, Davi de S. Fernandes ${ }^{5}$, Daniel R. Sosa-Gómez ${ }^{6}$, Adeney de F. Bueno ${ }^{6}$, Celso Omoto ${ }^{5}$, Geraldo U. Berger ${ }^{7}$, Alberto S. Corrêa ${ }^{5}$, Samuel Martinelli ${ }^{3}$, Patrick M. Dourado7 \& Graham Head ${ }^{3}$

Widespread adoption of MON $87701 \times$ MON 89788 soybean, expressing Cry1Ac Bt protein and glyphosate tolerance, has been observed in Brazil. A proactive program was implemented to phenotypically and genotypically monitor Cry1Ac resistance in Chrysodeixis includens (Walker). Recent cases of unexpected injury in MON $87701 \times$ MON 89788 soybean were investigated and a large-scale sampling of larvae on commercial soybean fields was performed to assess the efficacy of this technology and the distribution of lepidopteran pests in Brazil. No significant shift in C. includens susceptibility to Cry1Ac was observed eight years after commercial introduction of this technology in Brazil. $F_{2}$ screen results confirmed that the frequency of Cry1Ac resistance alleles remains low and stable in $C$. includens. Unexpected injury caused by Rachiplusia nu (Guenée) and Crocidosema aporema (Walsingham) in MON $87701 \times$ MON 89788 soybean was detected during the 2020/21 season, and studies confirmed a genetically based alteration in their susceptibility to Cry1Ac. MON $87701 \times$ MON 89788 soybean remains effective against Anticarsia gemmatalis (Hübner), $C$. includens, Chloridea virescents (Fabricius) and Helicoverpa armigera (Hübner) in Brazil. However, there is evidence of field-evolved resistance to MON $87701 \times$ MON 89788 soybean by the secondary soybean pests R. nu and C. aporema.

Pest management in commercial fields of soybean [Glycine max L. (Merr.)] in South America has been transformed by the introduction of MON $87701 \times$ MON 89788 soybean biotechnology (commercial name Intacta RR2 PRO). MON $87701 \times$ MON 89788 expresses the Cry1Ac (event MON 87701) protein from Bacillus thuringiensis $(B t)$ var. kurstaki at high levels all season long ${ }^{1,2}$, and tolerance to glyphosate is conferred by the event MON 89788, which expresses CP4 EPSPS. Brazil was the first country to adopt MON $87701 \times$ MON 89788 soybean in 2013/14. Eight years after its first commercial cultivation, more than 30 million hectares have been cultivated with this technology in Brazil (80\% of the country's soybean acreage) in the 2020/21 crop season ${ }^{3}$.

The high adoption rate of MON $87701 \times$ MON 89788 soybean has been driven by the significant yield advantage of varieties containing this technology and the high levels of protection against the primary soy lepidopteran pests in Brazil. MON $87701 \times$ MON 89788 soybean provides effective protection against larval feeding by Anticarsia gemmatalis (Hübner, 1818) (Lepidoptera: Erebidae), Chrysodeixis includens (Walker, [1858]), Chloridea virescens (Fabricius, 1781) and Helicoverpa armigera (Hübner, 1808) (Lepidoptera: Noctuidae) $)^{4-7}$.

The development of resistance in populations of the target pests to transgenic plants expressing $B t$ insecticidal proteins has been the main threat to the sustainability of these technologies ${ }^{8,9}$. The refuge strategy has been recommended as the major insect resistance management (IRM) strategy for delaying resistance in target pest populations of MON $87701 \times$ MON 89788 soybean $^{1,4,6,10}$. The assumption is that a $B t$ plant expressing

\footnotetext{
${ }^{1}$ Bayer Crop Science, Santa Cruz das Palmeiras, SP, Brazil. 'Departamento de Defesa Fitossanitária, Universidade Federal de Santa Maria, Santa Maria, Rio Grande Do Sul, RS, Brazil. ${ }^{3}$ Regulatory Science, Bayer Crop Science US, Chesterfield, MO, USA. ${ }^{4}$ Fundação ABC, Castro, PR, Brazil. ${ }^{5}$ Departamento de Entomologia e Acarologia, Escola Superior de Agricultura "Luiz de Queiroz", Universidade de São Paulo, Piracicaba, SP, Brazil. ${ }^{6}$ Empresa Brasileira de Pesquisa Agropecuária - Embrapa Soja, Londrina, Paraná, PR, Brazil. ${ }^{7}$ Bayer Crop Science, São Paulo, SP, Brazil. ${ }^{-}$email: renato.horikoshi@bayer.com
} 
a high dose of the $B t$ protein would control most or all of the individuals heterozygous for resistance alleles in natural populations, making resistance functionally recessive. When a sufficient refuge of non- $B t$ plants is available near a $B t$ field, the rare homozygous resistant insects that survive on $B t$ plants mate with the relatively abundant homozygous susceptible insects in the refuge. As a result, the heterozygous offspring produced would not survive on the high-dose $B t$ crop, substantially delaying the evolution of resistance ${ }^{11}$. The technical refuge recommendation for MON $87701 \times$ MON 89788 soybean in Brazil is planting at least $20 \%$ of the soybean acreage as a structured refuge formed by non- $B t$ soybean and located within $800 \mathrm{~m}$ of the $B t$ crop area ${ }^{12}$. However, low compliance with structured refuge recommendations seems to be a common theme across most of the cases of insect resistance to $B t$ crops documented globally ${ }^{13-21}$. This highlights the importance of programs to monitor the development of insect resistance to MON $87701 \times$ MON 89788 soybean and assess the adoption of refuge planting according to the technical recommendations for this technology in Brazil.

In addition to protecting against the insect species already mentioned, MON $87701 \times$ MON 89788 soybean also offers protection against larval injury caused by Rachiplusia nu (Guenée, 1852) (Lepidoptera: Noctuidae) and Crocidosema aporema (Walsingham, 1914) (Lepidoptera: Tortricidae) ${ }^{1}$. Rachiplusia $n u$ and C. aporema are historically considered key soy lepidopteran pests in Argentina ${ }^{22-24}$; in Brazil, however, the occurrence of these species in soybean fields has historically been restricted to reasonably low levels in the mid-south region of the country ${ }^{25-27}$. Cases of unexpected injury to the MON $87701 \times$ MON 89788 soybean caused by "loopers" were identified during the $2020 / 21$ crop season. We investigated these cases and here we report that the insects causing unexpected injury were $R . n u$ and C. aporema.

The goals of this paper are to (a) report data from the proactive resistance monitoring of $C$. includens to MON $87701 \times$ MON 89788 soybean in Brazil; (b) characterize the level of CrylAc resistance in $R$. $n u$ and $C$. aporema samples collected during the 2020/21 season; and (c) assess the efficacy of the MON $87701 \times$ MON 89788 technology and abundance of key lepidopteran pests in the 2020/21 season.

\section{Methods}

Proactive MON $87701 \times$ MON 89788 soybean resistance monitoring of $C$. includens. Insect samples and permits. To proactively monitor resistance to CrylAc protein expressed in Bt soybean, C. includens larvae were sampled from commercial plantings of non-Bt soybeans in distinct geographic regions of Brazil and sent to a laboratory in our monitoring network, where they were reared on artificial diet ${ }^{28}$ to obtain $\mathrm{F}_{1}$ and $\mathrm{F}_{2}$ generation larvae for use in bioassays. All $C$. includens field populations sampled in Brazil are listed in Tables 1, 2, 3 of the Supporting Information (SI). All insect collections in Brazil were done in accordance with the approval granted by the System of Authorization and Information on Biodiversity (SISBIO) of the Ministry of Environment to a contracted company responsible for the field sampling (PROMIP, Permit for scientific purpose activity: 61826 and 61824).

The research did not involve the collection of plant material in nature. All plants used in the study were grown from commercially available seeds. The study complies with relevant institutional, national, and international guidelines and legislation.

Phenotypic resistance monitoring of $C$. includens using a diagnostic concentration of CrylAc protein. Dietincorporated bioassays were performed with a Cryl Ac formulated product (MVP II, Pseudomonas encapsulated Cry1Ac from Dow Chemicals, San Diego, CA, containing 11.14\% of active Cry1Ac protein). As described in Yano et al. ${ }^{10}, 5.6 \mu \mathrm{g}$ of CrylAc protein/mL of diet was used as the diagnostic concentration for resistance monitoring in C. includens populations (SI Table 1). For the bioassays, the Cry1Ac protein was diluted in distilled water to $56 \mu \mathrm{g} / \mathrm{mL}$ and $4 \mathrm{~mL}$ of this solution was poured into a $50-\mathrm{mL}$ Falcon tube. The tube was then filled with $36 \mathrm{~mL}$ of artificial diet ${ }^{28}$. The mixture was homogenized in a vortex mixer for $\sim 40 \mathrm{~s}$. Then, $1 \mathrm{~mL}$ of diet containing CrylAc protein was poured into each well of a 128-well bioassay tray (BIO-BA-128; CD International Inc., Pitman, NJ). After the diet had dried, one neonate larva ( $<24 \mathrm{~h}$ old) from the $\mathrm{F}_{1}$ generation was placed into each well with a fine brush. Trays were sealed with a plastic adhesive (BIO-CV-16; CD International Inc.) that allowed air exchange and kept in a climatic chamber at $25 \pm 2{ }^{\circ} \mathrm{C}, 70 \pm 10 \% \mathrm{RH}$ and $14: 10 \mathrm{~h}$ (L:D) photoperiod. Mortality was recorded at 7 days. A total of 1,024 neonates/population were tested. Mortality data for each population were plotted on a time scale from 2015/16 (2016) to 2020/21 (2021). Data from 2009/10-2014/15 were previously reported in Yano et al. ${ }^{10}$ and plotted herein.

Genotypic Cry1Ac resistance monitoring of $C$. includens using $F_{2}$ screens. To estimate the CrylAc resistance allele frequency in Brazilian populations of $C$. includens, we utilized the $\mathrm{F}_{2}$ screen method proposed by Andow and Alstad ${ }^{29}$. From 2016/17 (2017) to 2020/21 (2021), a total of 74 populations of C. includens were screened (SI Table 2). The collected larvae were transported to a laboratory and kept on artificial diet ${ }^{28}$. After pupation, pupae were separated by sex and used to establish multiple single-pair mating couples under laboratory conditions. The offspring ( $F_{1}$ progeny) of each single-pair mating (isoline) were reared in artificial diet, and pupae were transferred to a PVC cylindrical cage $(20 \mathrm{~cm}$ height $\times 10 \mathrm{~cm}$ diameter) lined with paper (oviposition substrate) and covered with a mesh fabric until adult emergence. Adults were fed with a $10 \%$ honey solution provided on cotton inside a plastic cup. Eggs were collected and kept in plastic cups with filter paper moistened with water. $\mathrm{F}_{2}$ generation neonates ( $\leq 24 \mathrm{~h}$ old) were then used for screening. For the bioassays, leaves from the upper third of greenhouse-grown soybean plants were collected and kept in a refrigerator until use. Each isoline was tested in 128-well bioassay trays (BIO-BA-128; CD International Inc.) containing a 2\% agar solution and one soybean leaf disc of $1.7 \mathrm{~cm}$ diameter. Two neonate larvae $(<24 \mathrm{~h}$ old $)$ were placed in each well with a fine brush, with a target number of 128 neonates tested/isoline in 2016/17 (2017) and 256 neonates tested/isoline for 2017/18 to 2020/21 (2018-2021). Then, plates were sealed and placed under the same environmental conditions described above. 


\begin{tabular}{|c|c|c|c|c|c|c|c|c|}
\hline \multirow[b]{2}{*}{ Location } & \multicolumn{2}{|c|}{ Number of tested } & \multicolumn{2}{|l|}{$\begin{array}{l}\text { Number of } \\
\text { survivors }\end{array}$} & \multirow[b]{2}{*}{$\mathrm{F}_{2}$ lines surviving at 4 days } & \multirow{2}{*}{$\begin{array}{l}F_{2} \text { lines surviving at pupa } \\
\text { stage }\end{array}$} & \multirow[b]{2}{*}{ Resistance allele frequency } & \multirow[b]{2}{*}{$95 \% \mathrm{CI}$} \\
\hline & $F_{2}$ lines & Larvae & Larvae 4d & Pupa & & & & \\
\hline \multicolumn{9}{|l|}{ 2016/17 soybean season } \\
\hline Sapezal, MT & 50 & 3,408 & 0 & 0 & 0 & 0 & 0.0048 & $0.0001-0.0177$ \\
\hline Uberlândia, MG & 52 & 5,920 & 2 & 1 & 2 & 1 & 0.0139 & $0.0029-0.0332$ \\
\hline Casa Branca, SP & 44 & 6,048 & 2 & 1 & 1 & 1 & 0.0109 & $0.0013-0.0301$ \\
\hline Campo Verde, MT & 37 & 5,577 & 1 & 0 & 1 & 0 & 0.0128 & $0.0076-0.0162$ \\
\hline $\begin{array}{l}\text { Luís Eduardo Magalhães, } \\
\text { BA }\end{array}$ & 95 & 12,066 & 15 & 11 & 6 & 6 & 0.0180 & $0.0073-0.0335$ \\
\hline Correntina, BA & 111 & 15,104 & 18 & 13 & 11 & 9 & 0.0265 & $0.0138-0.0432$ \\
\hline Campo Mourão, PR & 89 & 9,840 & 0 & 0 & 0 & 0 & 0.0027 & $0.0001-0.0101$ \\
\hline Campo Grande, MS & 13 & 1,984 & 5 & 2 & 2 & 2 & 0.0501 & $0.0107-0.1173$ \\
\hline Não-Me-Toque, RS & 57 & 7,360 & 0 & 0 & 0 & 0 & 0.0043 & $0.0001-0.0156$ \\
\hline Rolândia, PR & 36 & 4,224 & 3 & 1 & 3 & 1 & 0.0264 & $0.0073-0.0570$ \\
\hline $\operatorname{Brazil}(2016 / 17)$ & 584 & 71,531 & 46 & 29 & 26 & 20 & 0.0115 & $0.0076-0.0162$ \\
\hline \multicolumn{9}{|l|}{$2017 / 18$ soybean season } \\
\hline Campo Grande, MS & 50 & 8,480 & 0 & 0 & 0 & 0 & 0.0048 & $0.0001-0.0178$ \\
\hline Campo Verde, MT & 50 & 11,232 & 0 & 0 & 0 & 0 & 0.0048 & $0.0001-0.0178$ \\
\hline Londrina, PR & 62 & 13,664 & 0 & 0 & 0 & 0 & 0.0039 & $0.0001-0.0144$ \\
\hline $\begin{array}{l}\text { Luís Eduardo Magalhães, } \\
\text { BA }\end{array}$ & 81 & 13,408 & 0 & 0 & 0 & 0 & 0.0030 & $0.0001-0.0111$ \\
\hline Rio Verde, GO & 58 & 6,944 & 0 & 0 & 0 & 0 & 0.0042 & $0.0001-0.0154$ \\
\hline Campo Mourão, PR & 18 & 2,560 & 5 & 4 & 1 & 1 & 0.0251 & $0.0031-0.0687$ \\
\hline Cristalina, GO & 27 & 4,152 & 0 & 0 & 0 & 0 & 0.0084 & $0.0002-0.0307$ \\
\hline Dourados, MS & 28 & 4,832 & 0 & 0 & 0 & 0 & 0.0084 & $0.0002-0.0307$ \\
\hline Ponta Grossa, PR & 48 & 7,578 & 14 & 0 & 4 & 0 & 0.0250 & $0.0082-0.0507$ \\
\hline Casa Branca, SP & 33 & 4,128 & 0 & 0 & 0 & 0 & 0.0072 & $0.0002-0.0263$ \\
\hline Uberlândia, MG & 37 & 4,128 & 1 & 0 & 1 & 0 & 0.0129 & $0.0016-0.0355$ \\
\hline Não-Me-Toque, RS & 20 & 2,976 & 0 & 0 & 0 & 0 & 0.0115 & $0.0003-0.0417$ \\
\hline Bagé, RS & 10 & 1,088 & 0 & 0 & 0 & 0 & 0.0210 & $0.0005-0.0759$ \\
\hline Brazil (2017/18) & 522 & 85,170 & 20 & 4 & 6 & 1 & 0.0033 & $0.0013-0.0062$ \\
\hline \multicolumn{9}{|l|}{ 2018/19 soybean season } \\
\hline Correntina, BA & 169 & 36,160 & 12 & 7 & 3 & 1 & 0.0058 & $0.0016-0.0128$ \\
\hline $\begin{array}{l}\text { Luís Eduardo Magalhães, } \\
\text { BA }\end{array}$ & 78 & 12,768 & 2 & 0 & 2 & 0 & 0.0093 & $0.0094-0.0225$ \\
\hline Roda Velha, BA & 22 & 4,480 & 0 & 0 & 0 & 0 & 0.0104 & $0.0003-0.0383$ \\
\hline Cristalina, GO & 62 & 12,112 & 3 & 3 & 2 & 2 & 0.0117 & $0.0024-0.0281$ \\
\hline Rio Verde, GO & 58 & 13,120 & 0 & 0 & 0 & 0 & 0.0042 & $0.0001-0.0154$ \\
\hline Tasso Fragoso, MA & 92 & 21,280 & 5 & 2 & 2 & 2 & 0.0027 & $0.0001-0.0098$ \\
\hline Campo Grande, MS & 117 & 44,582 & 21 & 15 & 6 & 6 & 0.0126 & $0.0046-0.0244$ \\
\hline Maracaju, MS & 76 & 16,448 & 0 & 0 & 0 & 0 & 0.0032 & $0.0001-0.0118$ \\
\hline Campo Verde, MT & 30 & 4,292 & 0 & 0 & 0 & 0 & 0.0078 & $0.0002-0.0287$ \\
\hline Campo Mourão, PR & 108 & 24,224 & 6 & 1 & 4 & 0 & 0.0114 & $0.0037-0.0231$ \\
\hline Londrina, PR & 127 & 29,312 & 1 & 0 & 1 & 0 & 0.0039 & $0.0005-0.0108$ \\
\hline Passo Fundo, RS & 17 & 3,028 & 1 & 1 & 1 & 1 & 0.0264 & $0.0033-0.0723$ \\
\hline Casa Branca, SP & 90 & 19,056 & 3 & 3 & 2 & 2 & 0.0082 & $0.0017-0.0196$ \\
\hline Chapadão do Sul, MS & 36 & 4,384 & 0 & 0 & 0 & 0 & 0.0066 & $0.0002-0.0243$ \\
\hline Lucas do Rio Verde, MT & 44 & 6,800 & 0 & 0 & 0 & 0 & 0.0055 & $0.0001-0.0201$ \\
\hline Rondonópolis, MT & 49 & 8,912 & 0 & 0 & 0 & 0 & 0.0049 & $0.0001-0.0181$ \\
\hline $\begin{array}{l}\text { Luís Eduardo Magalhães, } \\
\text { BA }\end{array}$ & 55 & 10,464 & 10 & 0 & 6 & 0 & 0.0044 & $0.0001-0.0162$ \\
\hline Brazil (2018/19) & 1230 & 271,422 & 64 & 29 & 29 & 12 & 0.0061 & $0.0041-0.0084$ \\
\hline \multicolumn{9}{|l|}{ 2019/20 soybean season } \\
\hline Campo Verde, MT & 86 & 20,128 & 0 & 0 & 0 & 0 & 0.0028 & $0.0001-0.0105$ \\
\hline $\begin{array}{l}\text { Luís Eduardo Magalhães, } \\
\text { BA }\end{array}$ & 144 & 30,256 & 14 & 2 & 3 & 1 & 0.0068 & $0.0018-0.0149$ \\
\hline Rio Verde, GO & 99 & 21,696 & 0 & 0 & 0 & 0 & 0.0025 & $0.0001-0.0092$ \\
\hline Campo Mourão, PR & 113 & 16,363 & 9 & 0 & 3 & 0 & 0.0087 & $0.0024-0.0190$ \\
\hline
\end{tabular}




\begin{tabular}{|c|c|c|c|c|c|c|c|c|}
\hline \multirow[b]{2}{*}{ Location } & \multicolumn{2}{|c|}{ Number of tested } & \multicolumn{2}{|l|}{$\begin{array}{l}\text { Number of } \\
\text { survivors }\end{array}$} & \multirow[b]{2}{*}{$F_{2}$ lines surviving at 4 days } & \multirow{2}{*}{$\begin{array}{l}\mathrm{F}_{2} \text { lines surviving at pupa } \\
\text { stage }\end{array}$} & \multirow[b]{2}{*}{ Resistance allele frequency } & \multirow[b]{2}{*}{$95 \%$ CI } \\
\hline & $F_{2}$ lines & Larvae & Larvae 4d & Pupa & & & & \\
\hline Correntina, BA & 129 & 20,572 & 19 & 12 & 1 & 1 & 0.0038 & $0.0005-0.0106$ \\
\hline Maracaju, MS & 112 & 18,226 & 5 & 4 & 2 & 2 & 0.0066 & $0.0014-0.0158$ \\
\hline Campo Grande, MS & 67 & 17,912 & 0 & 0 & 0 & 0 & 0.0036 & $0.0001-0.0134$ \\
\hline Cascavel, PR & 63 & 15,328 & 1 & 0 & 1 & 0 & 0.0077 & $0.0009-0.0214$ \\
\hline Chapadão do Sul, MS & 24 & 5,536 & 3 & 0 & 1 & 0 & 0.0193 & $0.0024-0.0530$ \\
\hline Cristalina, GO & 104 & 15,844 & 49 & 17 & 2 & 1 & 0.0071 & $0.0015-0.0170$ \\
\hline Londrina, PR & 97 & 20,512 & 1 & 0 & 1 & 0 & 0.0051 & $0.0006-0.0140$ \\
\hline Ponta Grossa, PR & 23 & 4,384 & 1 & 0 & 1 & 0 & 0.0200 & $0.0024-0.0551$ \\
\hline Tasso Fragoso, BA & 67 & 7,640 & 1 & 0 & 1 & 0 & 0.0072 & $0.0009-0.0201$ \\
\hline Uberlândia, MG & 132 & 28,165 & 10 & 2 & 3 & 1 & 0.0075 & $0.0020-0.0163$ \\
\hline Bagé, RS & 106 & 19,714 & 9 & 0 & 4 & 0 & 0.0116 & $0.0038-0.0236$ \\
\hline Correntina, BA & 64 & 15,040 & 0 & 0 & 0 & 0 & 0.0038 & $0.0001-0.0140$ \\
\hline $\begin{array}{l}\text { Luís Eduardo Magalhães, } \\
\text { BA }\end{array}$ & 94 & 23,200 & 25 & 4 & 2 & 1 & 0.0078 & $0.0016-0.0187$ \\
\hline Chapadão do Sul, MS & 63 & 15,232 & 2 & 0 & 1 & 0 & 0.0077 & $0.0009-0.0214$ \\
\hline Brazil (2019/20) & 1587 & 315,748 & 149 & 41 & 26 & 7 & 0.0042 & $0.0028-0.0060$ \\
\hline \multicolumn{9}{|l|}{$2020 / 21$ soybean season } \\
\hline Campo Verde, MT & 139 & 20,799 & 28 & 22 & 9 & 7 & 0.0177 & $0.0085-0.0301$ \\
\hline Cristalina, GO & 85 & 19,040 & 11 & 3 & 3 & 2 & 0.0115 & $0.0031-0.0251$ \\
\hline Sapezal, MT & 56 & 9,216 & 0 & 0 & 0 & 0 & 0.0043 & $0.0001-0.0159$ \\
\hline Correntina, BA & 135 & 25,797 & 18 & 14 & 5 & 3 & 0.0109 & $0.0040-0.0212$ \\
\hline Cascavel, PR & 121 & 18,000 & 4 & 2 & 1 & 1 & 0.0041 & $0.0005-0.0113$ \\
\hline Londrina, PR & 93 & 18,080 & 0 & 0 & 0 & 0 & 0.0026 & $0.0001-0.0097$ \\
\hline Maracaju, MS & 99 & 17,433 & 17 & 0 & 4 & 0 & 0.0124 & $0.0040-0.0252$ \\
\hline Uberlândia, MG & 101 & 20,717 & 0 & 0 & 0 & 0 & 0.0024 & $0.0001-0.0089$ \\
\hline Rio Verde, GO & 120 & 18,057 & 2 & 0 & 1 & 0 & 0.0041 & $0.0005-0.0114$ \\
\hline Passo Fundo, RS & 65 & 9,051 & 0 & 0 & 0 & 0 & 0.0037 & $0.0001-0.0138$ \\
\hline Campo Grande, MS & 87 & 15,776 & 0 & 0 & 0 & 0 & 0.0028 & $0.0001-0.0104$ \\
\hline Roda Velha, BA & 102 & 15,445 & 0 & 0 & 0 & 0 & 0.0024 & $0.0001-0.0089$ \\
\hline Campo Mourão, PR & 128 & 23,562 & 48 & 29 & 9 & 8 & 0.0192 & $0.0092-0.0326$ \\
\hline Tasso Fragoso, MA & 64 & 10,236 & 0 & 0 & 0 & 0 & 0.0038 & $0.0001-0.0140$ \\
\hline Lucas do Rio Verde, MT & 68 & 11,424 & 0 & 0 & 0 & 0 & 0.0036 & $0.0001-0.0132$ \\
\hline Conchal, SP & 50 & 8,928 & 0 & 0 & 0 & 0 & 0.0048 & $0.0001-0.0177$ \\
\hline Brazil (2020/21) & 1513 & 261,561 & 128 & 70 & 32 & 21 & 0.0054 & $0.0037-0.0074$ \\
\hline
\end{tabular}

Table 1. Frequency of resistance alleles conferring resistance of C. includens to MON $87701 \times$ MON 89788 soybean in Brazil from 2016/17 to 2020/21.

\begin{tabular}{|c|c|c|c|c|c|c|}
\hline \multirow[b]{2}{*}{ Species } & \multirow[b]{2}{*}{$n$} & \multicolumn{3}{|c|}{ Fit of probit lines } & \multirow[b]{2}{*}{$\mathrm{LC}_{50}(95 \% \mathrm{CI})^{\ddagger}$} & \multirow[b]{2}{*}{$\mathbf{T R}^{5}$} \\
\hline & & Slope \pm SE & $\chi^{2}\left(d f^{\dagger}\right)$ & $P$ & & \\
\hline R. $n u$ & 399 & $1.60 \pm 1.49$ & $1.77(5)$ & 0.22 & $>74,600.00$ (not estimated) & $>2,709$ \\
\hline C. includens & 192 & $2.16 \pm 0.48$ & $7.95(3)$ & 0.16 & $27.53(15.23-43.62)$ & \\
\hline
\end{tabular}

Table 2. Concentration-mortality response (ng CrylAc/cm ${ }^{2}$ ) of C. includens and R. nu neonates exposed to purified CrylAc protein in diet-overlay bioassay. ${ }^{\dagger} d f=$ degrees of freedom. ${ }^{\ddagger} \mathrm{LD}_{50}$ and $95 \%$ confidence interval (95\% CI). ${ }^{\S}$ Tolerance Ratio (TR) $=\mathrm{LC}_{50}$ of $R . n u / \mathrm{LC}_{50}$ of C. includens.

Survivorship was recorded after 4 days. If any survivors were found on MON $87701 \times$ MON 89788 soybean after 4 days, the leftover leaf discs were tested for Cry1Ac expression using QuickStix kits for Cry1Ac (Envirologix, Portland, Maine, USA). An isoline was considered positive (putative resistant) if any survivor was detected on MON $87701 \times$ MON 89788 soybean. To estimate the resistance allele frequency, we used the equation presented in Andow and Alstad ${ }^{29}$, and the $95 \%$ confidence intervals were estimated as described by Andow and Alstad ${ }^{30}$. The resistance allele frequency was calculated using the function binom.bayes from the package binom in $\mathrm{R}$ statistical software- $\mathrm{R}$ version $4.0 .2^{31}$. 


\begin{tabular}{|l|l|l|l|l|}
\hline Cross & $\boldsymbol{n}$ & ${\text { MON 87701 } \times \text { MON 89788 soybean }^{\dagger}}$ & Non- Bt soybean $^{\dagger}$ & Complementation $^{-1}$ \\
\hline Paranapanema 2020 $\times$ Uberaba 2020 & 192 & $4.6(2.3-8.5)$ a & $4.6(2.3-8.5)$ a & Yes \\
\hline Paranapanema 2020 $\times$ Taquarituba 2020 & 192 & $10.9(7.1-16.0)$ a & $7.8(4.6-12.3)$ a & Yes \\
\hline Paranapanema 2020 $\times$ Taquarituba 2021 & 192 & $3.6(1.6-7.1)$ a & $2.6(1.0-5.8)$ a & Yes \\
\hline Paranapanema 2020 $\times$ Perdizes 2021 & 192 & $7.8(4.6-12.3)$ a & $7.8(4.6-12.3)$ a & Yes \\
\hline
\end{tabular}

Table 3. Percent mortality ( $95 \%$ CIs) of $R$. $n u$ populations resistant to MON $87701 \times$ MON 89788 soybean in complementation test for allelism. ${ }^{\dagger}$ Values represent means $(95 \% \mathrm{CI})$. Mortality on MON $87701 \times \mathrm{MON}$ 89788 soybean and non- $B t$ soybean followed by the same letter in each row are not significantly different due to overlap of $95 \%$ CIs. No differences on mortality among MON $87701 \times$ MON 89788 soybean and non- Bt soybean indicates that the resistance alleles are probably in a same locus.

Reactive resistance monitoring: investigating unexpected injury to MON $87701 \times$ MON 89788 soybean in Brazil. After reports of unexpected injury to MON $87701 \times$ MON 89788 soybean commercial fields in Brazil, an investigation was initiated. Larvae were sampled from these fields to identify the lepidopteran species attacking the plants. Identifications of lepidopteran species were based on Herzog ${ }^{32}$, Navarro et al. ${ }^{33}$ and Gilligan and Passoa ${ }^{34}$ and indicated that $R$. $n u$ and C. aporema were the species injuring MON $87701 \times$ MON 89788 soybeans. These species were then investigated for resistance to CrylAc as described below.

Testing sampled R. nu field populations. To understand the unexpected plant injury and survival of $R$. nu in MON $87701 \times$ MON 89788 soybean fields in Brazil during the 2020/21 season, bioassays with Cry1Ac protein and leaf discs of MON $87701 \times$ MON 89788 soybean were carried out. Diet-overlay bioassays using Cry1Ac protein were used to test a $R$. nu population collected in Paranapanema, SP, Brazil (SI Table 3). A susceptible R. $n u$ laboratory colony was not available, so a susceptible laboratory population of $C$. includens was used as a standard for comparison of tolerance levels between the two species. The purified CrylAc insecticidal protein was produced by Bayer Crop Science US (Chesterfield, MO, USA). Proteins were isolated from fermentation broths of recombinant $B$. thuringiensis strains transformed to express individual toxins, like described in Chen et al. ${ }^{35}$ Bioassays were performed in 96-well bioassay trays with $200 \mu \mathrm{L}$ of artificial diet per well. Seven concentrations of CrylAc were prepared by dilution in TX buffer (0.005\% Triton X-100, $10 \mathrm{mM}$ Tris-HCl, pH 7.4). The control treatment was composed of TX buffer. After preparation, $20-\mu$ l protein samples were overlaid on the diet surface of each well and ventilated until the excess moisture dissipated. After drying, each well was infested with a single neonate larva $(<24 \mathrm{~h}$ old $)$ using a fine brush. Mortality was recorded at 6 days. Lethal concentrations $\left(\mathrm{LC}_{50}\right)$ and $95 \%$ confidence intervals were estimated using probit analysis in SAS $9.1^{36}$.

Leaf-disc bioassays were also performed with C. includens and $R$. nu field populations sampled from Brazil and Argentina (SI Table 3). Bioassays were conducted in the respective country of sampling with neonates from the $F_{1}$ to $F_{2}$ generations in Argentina and from the $F_{1}$ generation in Brazil. The MON $87701 \times$ MON 89788 soybean and non- $B t$ soybean were grown in a greenhouse. Seeds were sown on the ground within a greenhouse in Brazil, whereas in Argentina they were cultivated in $5 \mathrm{~L}$ plastic pots with 1 plant/pot. Nutrients and water were provided according to the necessity during plant development. Bioassays were performed with leaves of V6- to R3-growth-stage plants ${ }^{37}$ following the leaf-disc bioassay method previously described, but with the difference that a single neonate $(<24 \mathrm{~h}$ old $)$ was placed in each well. A total of 128 neonates was tested for each population/ treatment combination. Bioassay were carried out with 8 replicates of 16 larvae in Brazil and 4 replicates of 32 larvae in Argentina. Mortality was recorded at 4 days counting the number of dead larvae in each replicate. The percent mortality on MON $87701 \times$ MON 89788 soybean and non- $B t$ soybean. The total number of tested and dead insects on MON $87701 \times$ MON 89788 soybean and non-Bt soybean were used to estimate the $95 \%$ confidence interval (CI) for the probability of mortality, according to binomial distribution. The statistical analysis of the data from these bioassays was made using the function binom.probit from the package binom in $\mathrm{R}$ statistical software-R version 4.0.2 $2^{31}$. Percent mortality on MON $87701 \times$ MON 89788 soybean and non-Bt soybean were considered significantly different when their $95 \%$ CI did not overlap.

To determine whether the same resistance allele was present in populations of $R . n u$ sampled from distinct locations in Brazil, we also ran a complementation test for allelism. For this, the field population of $R$. $n u$ from Paranapanema sampled in 2020 was crossed with four other field populations (Uberaba 2020, Taquarituba 2020, Taquarituba 2021, Perdizes 2021) (SI Table 3). At least 15 pairs were used for each crossing. The $\mathrm{F}_{1}$ progeny were tested using leaf-disc bioassays as previously described, with 12 replicates of 16 larvae/cross, totaling 192 neonates tested on MON $87701 \times$ MON 89788 soybean and on non-Bt soybean. Mortality was recorded after 4 days, and data were compared as earlier described.

Testing sampled C. aporema field populations. To understand the unexpected injury and survival of C. aporema on MON $87701 \times$ MON 89788 soybean fields in Brazil during the 2020/21 soybean season, four populations were collected in different MON $87701 \times$ MON 89788 soybean fields with unexpected injury (SI Table 3). Neonates from these populations ( $F_{1}$ generation) were used in leaf-disc bioassays of MON $87701 \times$ MON 89788 soybean and non- $B t$ soybean as described in the previous section. Because only a limited number of eggs were available from the mass mating of field insects, only 13 neonates from the Itararé population and 32 neonates from the Cristalina, Perdizes and Tibagi populations were tested in each treatment. Mortality was recorded at 


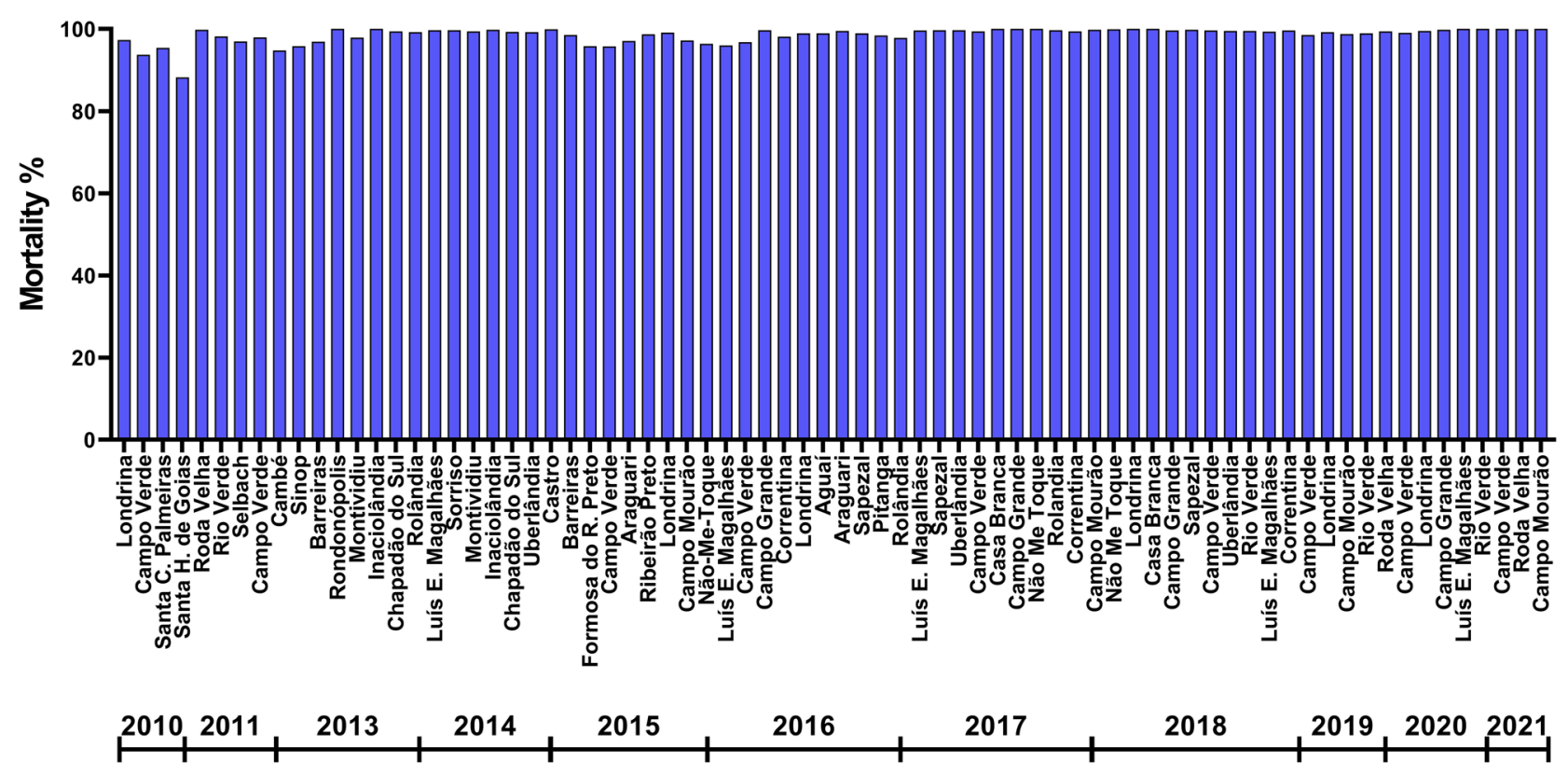

\section{Year/Location}

Figure 1. Susceptibility monitoring of C. includens populations from Brazil to Cryl Ac protein during 2009/102020/21 using diagnostic concentration bioassay. Data from 2009/10 to 2014/15 were reported previously in Yano et al. ${ }^{10}$.

4 days. The mortality data of each population on MON $87701 \times$ MON 89788 soybean and non- $B t$ soybean were compared as earlier described.

Abundance of lepidopteran pests on commercial fields of MON $87701 \times$ MON 89788 soybean and non-Bt soybean in Brazil. Lepidopteran larvae were sampled from 395 geographically distinct soybean fields during the 2020/21 cropping season. Each location comprised a non-Bt (Roundup Ready [RR]) soybean field and a MON $87701 \times$ MON 89788 soybean (Intacta RR2 PRO) field. A beat cloth (1-m length) was used to sample larvae. A total of 10 beats in a zig-zag pattern was considered the sampling unit. To minimize border effects, sampling was initiated from at least $20 \mathrm{~m}$ from the border of soybean fields in the Southern region farms, where farms are smaller (average size of farms less than $100 \mathrm{ha}$ ), and $100 \mathrm{~m}$ in the Northeast and Central-West regions, where larger farms are predominant (average size of farms greater than $150 \mathrm{ha}$ ). For each location, beat-cloth sampling started in the non- $B t$ field; when at least 1 lepidopteran larva per meter was found, samples were also taken from a nearby MON $87701 \times$ MON 89788 soybean field at a similar plant growth stage. The presence of CrylAc protein in MON $87701 \times$ MON 89788 soybean plants and the absence of this protein in non-Bt soybean plants were checked for Cry1Ac expression in all fields using QuickStix kits for Cry1Ac (Envirologix). Sampled larvae from each beat-cloth were transferred to a labeled $50-\mathrm{mL}$ conical Falcon tube containing propylene glycol. Tubes containing larvae were then sent to the laboratory and kept in a freezer $\left(-20^{\circ} \mathrm{C}\right)$ until identification. Identification of lepidopteran larvae were based on Herzog ${ }^{32}$, Sosa-Gómez et al. ${ }^{38}$, Navarro et al. ${ }^{33}$ and Gilligan and Passoa $^{34}$. Sampling fields were grouped according to the location within Embrapa's (Embrapa Soybean) soybean variety regionalization named "edaphoclimatic regions" and "soybean macroregions" 39.

Statistical modeling was used to characterize soybean geographic variation in pest abundance in non- $B t$ soybean and MON $87701 \times$ MON 89788 soybean. Specifically, random effects for edaphoclimatic regions were estimated separately for each pest and field type (non-Bt soybean and MON $87701 \times$ MON 89788 soybean) using a linear mixed-effects model for larval count data with Poisson link, with edaphoclimatic region and soybean macroregion treated as random effects, and edaphoclimatic region nested within soybean macroregion. An advantage of random effects estimates, compared to fixed effects estimates or simply using average counts by region, is that they properly account and adjust for sample size differences between regions, providing more accurate predictions of true pest density. The random effects estimates of pest abundance by edaphoclimatic region were summarized using choropleth maps. Analyses were performed with $\mathrm{R}$ statistical software- $\mathrm{R}$ version 4.0.2 $2^{31}$ using the glmer function in R package "lmer".

Refuge compliance and MON87701 × MON89788 soybean adoption in Brazil. Data on MON $87701 \times$ MON 89788 soybean adoption and strict refuge compliance across 46 to 51 mesoregions (number varied among years) for the 2014/15 to 2019/20 cropping seasons were obtained from market research companies Kynetec (2014/152017/18) and Spark (2018/19-2019/20). Mesoregions are Brazilian geographical division in a federative unit (state) defined by social process, natural and network of communication and places ${ }^{40}$. Figure 1 of the Supporting Information (SI) shows the mesoregions used in the analysis. A linear regression analysis was performed with 


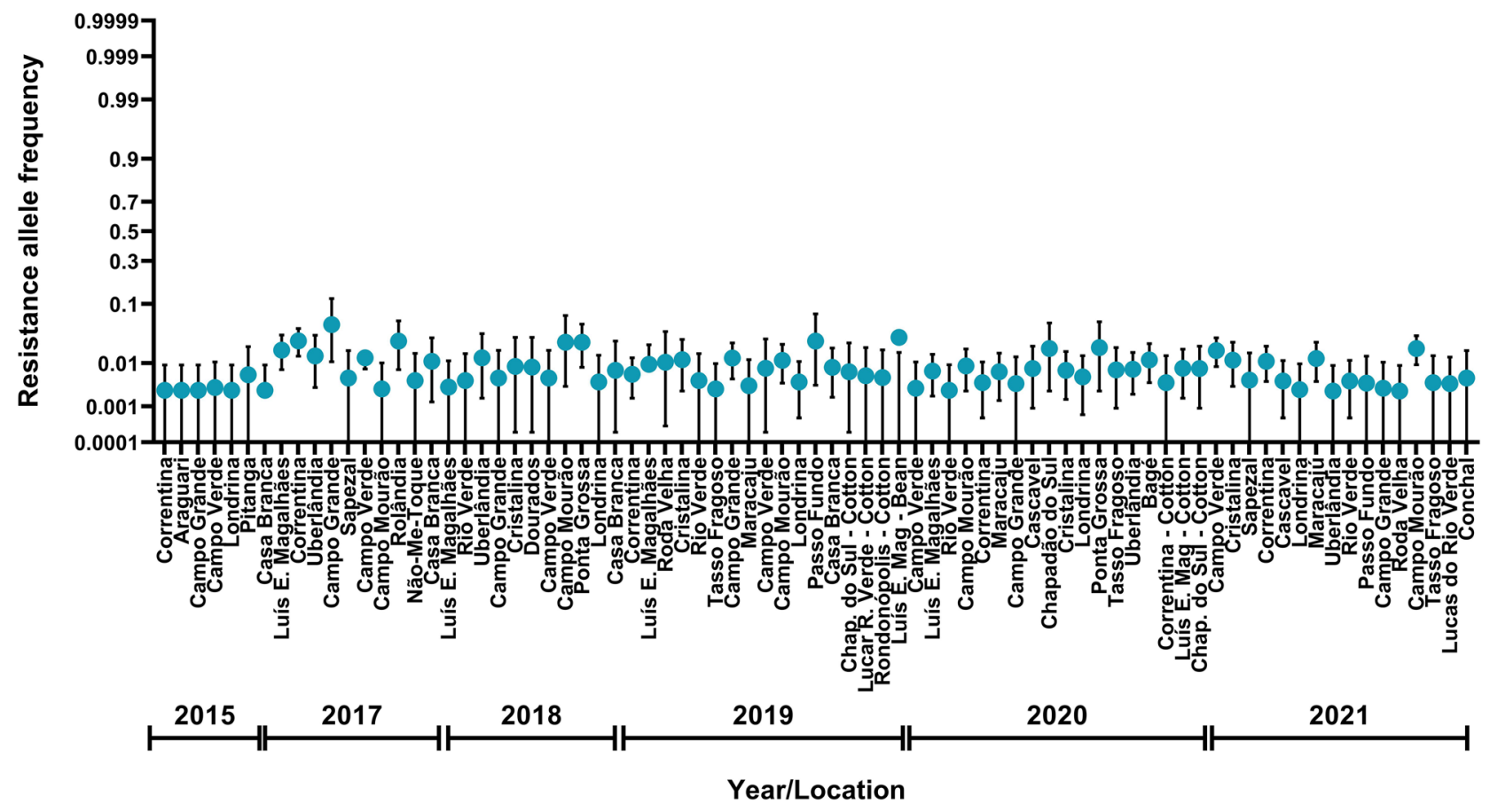

Figure 2. Frequency of resistance alleles conferring resistance of $C$. includens to MON $87701 \times$ MON 89788 soybean in Brazil. Data from 2014/15 were previously reported by Yano et al. $^{10}$.

the percentage of refuge compliance as a function of MON $87701 \times$ MON 89788 adoption, using GraphPad Prism 8-version 8.1.2 (GraphPad Software, San Diego, CA, USA) ${ }^{41}$.

\section{Results}

Proactive MON $87701 \times$ MON 89788 soybean resistance monitoring of $C$. includens. Phenotypic resistance monitoring in $C$. includens using a diagnostic concentration of Cry1Ac protein. There was high mortality in all field populations of $C$. includens collected from 2015/16 to 2020/21 (42 field populations) when exposed to the CrylAc diagnostic concentration of $5.6 \mu \mathrm{g}$ of Cryl Ac protein per $\mathrm{mL}$ of diet (Fig. 1). The neonate mortality in this period ranged from 96 to $100 \%$, not differing over time. Compared with data from 2009/102014/15, there was also no obvious change in the susceptibility to CrylAc protein in populations of C. includens from Brazil over the evaluated years (Fig. 1).

Genotypic Cry1Ac resistance monitoring in C. includens using $F_{2}$ screens. From 2016/17 to 2020/21, a total of 74 populations, 5,436 isolines and more than one million neonates of $C$. includens were screened on leaf discs of MON $87701 \times$ MON 89788 soybean. Resistance alleles were detected in 119 isolines (considered positive when any neonate survived on MON $87701 \times$ MON 89788 soybean at 4 days), with 61 isolines presenting larvae that reached pupal stage while feeding on MON $87701 \times$ MON 89788 soybean leaves (Table 1). The estimated resistance allele frequency decreased from 0.0115 (95\% CI, 0.0076-0.0162) in 2016/17 to 0.0033 (95\% CI, 0.0013-0.0062) in the $2017 / 18$ soybean season. However, resistance allele frequency remained similar in subsequent seasons: 0.0061 (95\% CI, 0.0041-0.0084) in 2018/19, 0.0042 (95\% CI, 0.0028-0.0060) in 2019/20, and $0.0054(95 \%, 0.0037-0.0074)$ in 2020/21. Across crop seasons and regions, the frequency of resistance alleles to MON $87701 \times$ MON 89788 soybean was also stable in C. includens populations from 2016/17 to 2020/21, suggesting no relevant shifts in susceptibility (values distributed among 0.0024 to 0.05 ) (Fig. 2), confirming the highly efficacious control of this key pest by MON $87701 \times$ MON 89788 soybean.

Reactive resistance monitoring: investigating unexpected injury to MON $87701 \times$ MON 89788 soybean caused by $R$. nu and C. aporema in Brazil. Testing sampled R. nu field populations. The Cryl Ac concentrations used to estimate $\mathrm{LC}_{50}$ in $R . n u$ from a MON $87701 \times$ MON 89788 soybean field in Brazil ranged from 1,165 to $74,600 \mathrm{ng} / \mathrm{cm}^{2}$. At these concentrations, the mortality of the $R$. $n u$ population ranged from 8.3 to $25.4 \%$. The $\mathrm{LC}_{50}$ of Cryl Ac and respective $95 \% \mathrm{CI}$ for this population could not be accurately estimated and was considered higher than $74,600 \mathrm{ng} / \mathrm{cm}^{2}$ (maximum concentration tested) (Table 2). In contrast, the susceptible C. includens laboratory population showed $100 \%$ mortality at $1.165 \mathrm{ng} / \mathrm{cm}^{2}$, with an $\mathrm{LC}_{50}$ of Cry1 Ac of 27.53 (95\% CI 15.23-43.62) ng/ $\mathrm{cm}^{2}$ (Table 2). The estimated ratio of tolerance to Cry1Ac protein was $>2,709$ for the $R$. $n u$ population tested. Significant differences in susceptibility to Cryl Ac protein between species were also verified by the equality $\left(\chi^{2}=230.0 ; d f=2 ; P<0.001\right)$ and parallelism $\left(\chi^{2}=130.3 ; d f=1 ; P<0.001\right)$ tests, which indicated that the mortality curves had distinct parameters (intercepts and slopes). 
When neonates of the $R$. nu population tested above and four other populations obtained in MON $87701 \times$ MON 89788 soybean fields in Brazil were exposed to MON $87701 \times$ MON 89788 soybean leaf discs, there was no higher than $9.4 \%$ mortality, not differing significantly from those verified on non$B t$ soybean controls (Fig. 3A). In contrast, $R$. nu populations from Argentina presented $100 \%$ mortality on MON $87701 \times$ MON 89788 soybean leaf discs and no higher than $12.5 \%$ mortality on non- $B t$ soybean. Similar results to those for $R$. $n u$ from Argentina were obtained for C. includens populations from Brazil and Argentina exposed to MON $87701 \times$ MON 89788 soybean ( $>99.2 \%$ mortality) and non- $B t$ soybean ( $<15 \%$ mortality) (Fig. 3B).

In the complementation study, there were no significant differences in the mortality of progeny from four crosses involving five populations of $R$. $n u$ from distinct MON $87701 \times$ MON 89788 soybean fields in Brazil when exposed to MON $87701 \times$ MON 89788 soybean (3.6 to 10.9\%) and non-Bt soybean (2.6 to 7.8\%) (Table 3). These results provide evidence against the hypothesis that the resistance alleles in any of the populations were at different loci and therefore suggest that the resistance alleles are probably at the same locus.

Overall, our results suggest a genetically based decrease in susceptibility to CrylAc protein expressed in soybean in the Brazilian populations of $R$. nu tested.

Testing sampled C. aporema field populations. The C. aporema populations sampled from Cristalina, Itararé, Perdizes and Tibagi showed similar mortality on MON $87701 \times$ MON 89788 soybean ( 0.0 to $15.6 \%)$ and non- $B t$ soybean (6.3 to $9.3 \%$ ) (Fig. 4). These results indicated a decrease in susceptibility to CrylAc protein expressed in MON $87701 \times$ MON 89788 soybean by C. aporema populations from Brazil.

Abundance of lepidopteran pests on commercial fields of MON $87701 \times$ MON 89788 soybean and non-Bt soybean in Brazil. A random effects statistical model was used to estimate pest abundance for each edaphoclimatic region. Separate analyses were conducted for each pest and field type. Pest abundance estimates were summarized using choropleth maps, where each edaphoclimatic region is color-coded according to its estimated pest abundance (different colors are assigned for estimates in the ranges $<0.10,0.1-0.25,0.25-0.5,0.5-1,1-2.5$, $2.5-5,5-10$, and $>10$ larvae/10 $\mathrm{m}$ ). In all maps that show more than one color, there is statistically significant variation across edaphoclimatic regions $(P<0.05)$ (Fig. 5).

The visualization of geographic variation in lepidopteran pest abundance in MON $87701 \times$ MON 89788 soybean and non- $B t$ soybean fields shows that $C$. includens was present at high density in 301 of the 395 sampling locations in non- $B t$ soybean (76.2\% of fields) but nearly absent (1.01\%) from MON $87701 \times$ MON 89788 soybean fields (Fig. 5). Anticarsia gemmatalis, Helicoverpa spp. and C. virescens were also nearly absent $(<0.51 \%)$ from MON $87701 \times$ MON 89788 soybean in almost all samples but were detected in $25.3,11.1$ and $2.3 \%$ of the non- $B t$ soybean fields, respectively (Fig. 5). Among the species analyzed, A. gemmatalis had the second-highest density on non-Bt soybean across the regions examined (Fig. 5). Crocidosema aporema larvae was observed at low density in non-Bt soybean fields in some areas of south and central Brazil (Fig. 5); however, the beat-cloth method is not the best method to sample this species so its incidence might have been underestimated. In contrast to other species, $R$. $n u$ larvae appeared in a moderate number of non- $B t$ soybean fields from south to central Brazil. Its occurrence was also detected in $5.5 \%$ of the MON $87701 \times$ MON 89788 soybean fields sampled, mainly in growing areas located in Paraná and São Paulo states (Fig. 5).

Refuge compliance and MON $87701 \times$ MON 89788 soybean adoption in Brazil. The compliance to refuge requirements significantly decreased with increasing MON $87701 \times$ MON 89788 adoption over mesoregions $\left(\mathrm{F}=290.8, \mathrm{df}=1,281, \mathrm{R}^{2}=0.51, P<0.0001\right)$ (Fig. $\left.6 \mathrm{~A}\right)$. The median refuge compliance in $2014 / 15$ was $82.1 \%$ and dropped to $21.4 \%$ in $2019 / 20$ (Fig. 6B).

\section{Discussion}

The proactive phenotypic and genotypic monitoring of CrylAc resistance did not show shifts in the susceptibility of C. includens that would lead to unexpected injury on MON $87701 \times$ MON 89788 soybean in the field. Although an initial shift was observed from the genotypic resistance baseline monitoring carried out in $2014 / 15^{10}$, our findings indicated that the resistance allele frequency did not increase significantly over the following years. Even though some $C$. includens larvae tested in our $\mathrm{F}_{2}$ screening survived on $\mathrm{MON} 87701 \times$ MON 89788 soybean leaves, most of the larvae that developed into adults did not produce fertile eggs, suggesting an incomplete resistance to Cry1 Ac in C. includens. If a major recessive trait confers resistance, $1 / 16$ of the $\mathrm{F}_{2}$ larvae are expected to be homozygous resistant and therefore able to complete their life cycle on a $B t$ plant ${ }^{29,42}$. Because the percentage of resistant larvae was much smaller than $1 / 16$, we hypothesized that minor genes were responsible for the survival of $C$. includens on MON $87701 \times$ MON 89788 soybean in our $F_{2}$ screening. The $\mathrm{F}_{2}$ screen method proposed by Andow and Alstad ${ }^{29}$ might not be the best way to estimate the resistance allele frequency of minor alleles involved with resistance, since it was developed to estimate the frequency of major resistance alleles. Although the resistance allele frequency might be biased with that method, it is still a good estimation of resistance allele frequency over the time, as we are using the same method over years. So far, no unexpected injury on MON $87701 \times \mathrm{MON}$ 89788 soybean was reported by $C$. includens, confirming the low resistance allele frequency detected in the $\mathrm{F}_{2}$ 

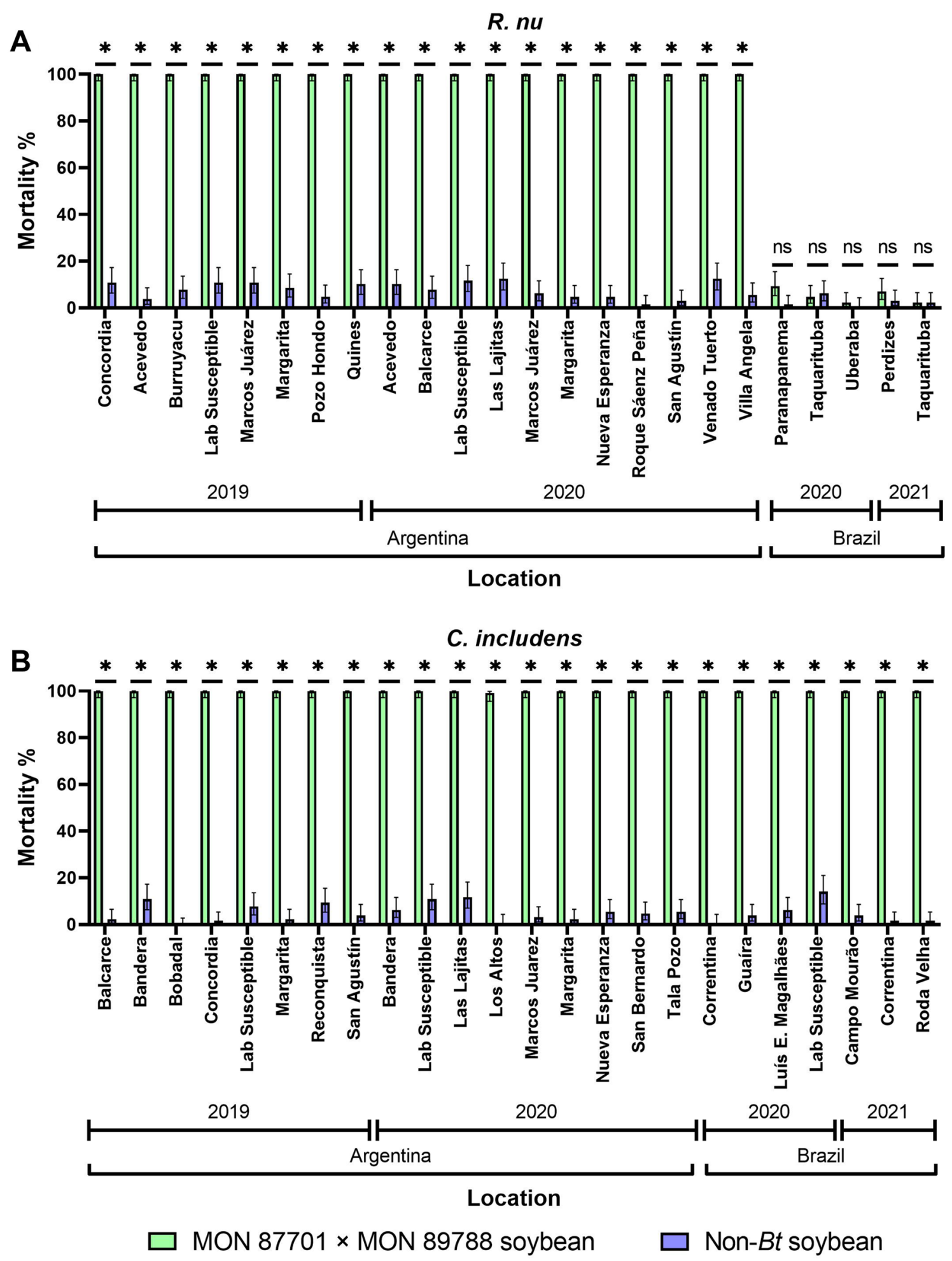

Figure 3. Mortality of R. nu (A) and C. includens (B) populations sampled from soybean fields in Argentina and Brazil on MON $87701 \times$ MON 89788 soybean and non- $B t$ soybean. The asterisk $\left({ }^{\star}\right)$ indicated that the mortality on MON $87701 \times$ MON 89788 soybean and non-Bt soybean differed significantly due to non-overlap of $95 \%$ CIs. ns = non-significant. 


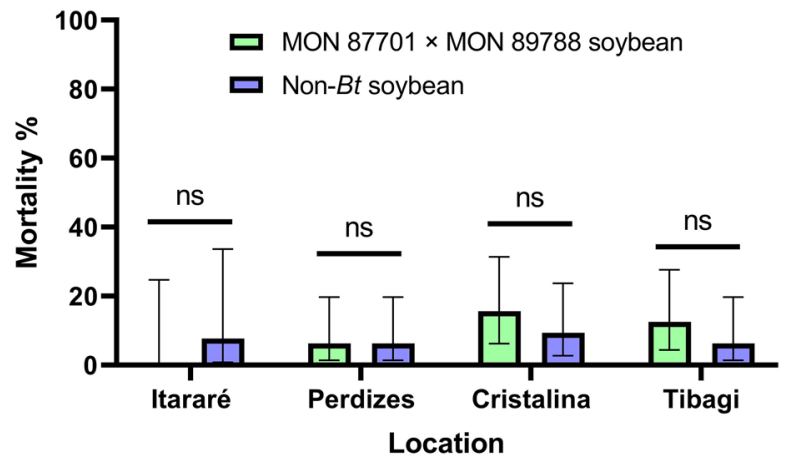

Figure 4. Percent mortality (95\% CI) of C. aporema populations on MON $87701 \times$ MON 89788 soybean and non- $B t$ soybean. $\mathrm{ns}=$ non-significant.

screens. We further hypothesized that the resistance alleles detected in our genetic monitoring might be strongly associated with fitness, since the $C$. includens adults did not produce viable offspring.

The high-dose/refuge strategy used for management of resistance to MON $87701 \times$ MON 89788 soybean seems to have contributed to maintaining a low frequency of resistance in natural populations of $C$. includens. In addition to the results previously published by MacRae et al. ${ }^{1}$ and Bernardi et al. ${ }^{4}$, further evidence supporting the functional recessiveness of Cry1 Ac resistance in C. includens exposed to MON $87701 \times$ MON 89788 soybean was obtained when a laboratory strain of $C$. includens selected on Cry1 Ac Bt cotton was crossed with susceptible insects and the $\mathrm{F}_{1}$ progeny showed complete mortality on MON $87701 \times \mathrm{MON} 89788$ soybean leaves ${ }^{43}$.

In contrast to previous results, unexpected injury caused by secondary target pests $R$. $n u$ and C. aporema was detected in MON $87701 \times$ MON 89788 soybean fields during the 2020/21 season. Although susceptible reference populations of these species were not available, differences were detected in the susceptibility to MON $87701 \times$ MON 89788 soybean among $R$. nu populations from Brazil and Argentina. Diet-overlay bioassays using Cry1Ac protein also indicated a high tolerance ratio ( $>2,709$-fold) for $R$. $n u$ sampled from MON $87701 \times$ MON 89788 soybean fields compared to $C$. includens from non- $B t$ soybean. A study conducted before the commercial launch of MON $87701 \times$ MON 89788 soybean showed that the LC $_{50}$ of CrylAc was 1.53 and $0.70 \mu \mathrm{g} / \mathrm{ml}$ of artificial diet for $C$. includens and $R$. $n u$, respectively ${ }^{44}$. These results indicated a tolerance ratio of $R$. $n u$ in relation to $C$. includens of 0.45 -fold, evidencing that these Plusiinae had similar susceptibility to Cry1Ac in Brazil. The complementation test results suggested that the resistance alleles are probably at the same locus in different field populations of $R . n u$ sampled from MON $87701 \times$ MON 89788 soybean fields in Brazil. Similarly, offspring of C. aporema sampled from MON $87701 \times$ MON 89788 soybean fields presented similar mortality on $B t$ and non- $B t$ soybean, suggesting a genetically based decrease in the susceptibility to CrylAc protein.

The development of resistance of $R$. $n u$ and C. aporema to MON $87701 \times$ MON 89788 soybean may have also been influenced by the biological characteristics of these species and of the cropping systems in Brazil. Historically, R. nu has been a soybean pest in the southern part of South America (Rio Grande do Sul state in Brazil, Uruguay and Argentina $)^{24,26,45}$. In a prior field survey in 2019 and 2020, $R$. nu occurred at a low level in Brazil ${ }^{7}$. However, $R$. $n u$ has increased in abundance in soybean areas at lower latitudes, which may indicate an adaptation of $R . n u$ populations to warmer climate conditions before evolving resistance to MON $87701 \times$ MON 89788 soybean. Low genetic distances between populations from different South American countries also suggest the absence of geographical isolation amongst these natural populations ${ }^{45}$. For C. aporema, the short lifecycle (12 days) allows the development of several generations per season, therefore increasing the selection pressure for resistance. The planting of common bean (Phaseolus vulgaris L.) combined with the presence of volunteer MON $87701 \times$ MON 89788 soybeans after crop harvest in field areas where these pests were found in southern Brazil creates a "green bridge" during the soybean off-season and increases the sequential exposure of these pests to MON $87701 \times$ MON 89788 soybean. Furthermore, the low adoption of structured refuges together with the overuse of insecticides in non- $B t$ areas ${ }^{46}$ likely played an important role in establishing field-evolved CrylAc resistance in these species. Reductions in refuge compliance might compromise the high-dose/refuge strategy recommended for MON $87701 \times$ MON 89788 soybean in Brazil. The common understanding is that the high yield of MON $87701 \times$ MON 89788 soybean varieties relative to most of the commercially available non- $B t$ soybean varieties and the relative ease of pest management relative to non- $B t$ soybean have led some growers to not comply with the refuge recommendation in Brazil. In addition, the planting of refuges is not mandatory in Brazil, and recommendations are mainly promoted by technology providers, adding more challenges for compliance to 
IRM requirements ${ }^{47}$. According to Tabashnik and Carrière ${ }^{11}$, low refuge compliance was a key factor in cases of field-evolved resistance to $B t$ plants worldwide. Moreover, the lack of adoption of Integrated Pest Management (IPM) practices, particularly in refuge areas, can increase the spraying of foliar insecticides in these areas, thus reducing the effectiveness of this important IRM strategy and favoring pest resurgence by likely reducing the abundance of biological control agents ${ }^{46}$. Despite the characteristics of $R$. nu and C. aporema that might have favored resistance development, the question remains why Cry1Ac resistance to MON $87701 \times$ MON 89788 soybeans evolved in these species but not in C. includens, the most abundant lepidopteran soybean pest in Brazil ${ }^{7}$, under the same refuge adoption and management settings as these other pests. The absence of field-evolved Cry1Ac resistance in C. includens in Brazil suggests that the mechanisms of Cry1Ac resistance in C. includens may be more complex and detrimental to fitness than those in $R$. $n u$ (or C. aporema). Understanding the genes and molecular mechanisms involved in CrylAc resistance in C. includens, $R$. $n u$ and C. aporema can provide important information to support additional modeling of the projected durability of MON $87701 \times$ MON 89788 soybeans in Brazil.

General assessment of injury in soybean fields indicated that MON $87701 \times$ MON 89788 soybean provides excellent protection against the main soybean lepidopteran pests in Brazil. Our sampling performed during the 2020/21 season showed that $C$. includens, A. gemmatalis and Helicoverpa spp. were nearly absent from MON $87701 \times$ MON 89788 soybean fields, showing the consistent efficacy of MON $87701 \times$ MON 89788 soybean in managing these lepidopteran species. Our results also demonstrate that $C$. includens and A. gemmatalis remain the most abundant primary lepidopteran pests in non- $B t$ soybean fields, confirming the results from previous research ${ }^{7}$. These species were widely distributed across the soybean-growing regions of Brazil, whereas $R$. $n u$, Helicoverpa spp. and C. aporema were less prevalent. It is important to note, however, that beat-cloth sampling does not provide an accurate count of C. aporema, so its occurrence might have been underestimated. From 1980 to the 2000s, A. gemmatalis was the main lepidopteran pest of soybean in Brazil ${ }^{48,49}$. However, from the early 2000s, C. includens emerged as the key pest, which was likely influenced by the expansion of the soybean crop in Brazil $^{50}$. In our results, $R . n u$ and C. aporema were restricted to soybean fields in the Mid-South of Brazil, probably due to their better adaptation to subtropical and temperate climate of this region ${ }^{25-27}$, whereas Helicoverpa spp. was present in soybean fields in the Central regions of Brazil. Chloridea virescens was practically absent from both MON $87701 \times$ MON 89788 soybean and non-Bt soybean fields.

Overall, we can conclude that MON $87701 \times$ MON 89788 soybean remains effective against $A$. gemmatalis, C. includens, Helicoverpa spp. and C. virescens after eight years of commercial plantings in Brazil. However, we also report the first evidence of field-evolved resistance to MON $87701 \times$ MON 89788 soybean in the secondary soybean pests $R$. $n u$ and C. aporema. Our results indicate the MON $87701 \times$ MON 89788 soybean continues to be a highly valuable and efficacious IPM tool that soybean growers in Brazil can rely on to manage the major pests C. includens and A. gemmatalis despite the localized cases of CrylAc resistance documented in secondary soybean lepidopteran pests. However, the increasing adoption of Bt soybean technology and the decrease in structured refuge compliance, along with these first and still localized cases of CrylAc resistance documented in secondary lepidopteran pests, highlights the importance of IRM practices.

To maintain the benefits of MON $87701 \times$ MON 89788 soybean against primary target pests such as $C$. includens and $A$. gemmatalis, it is important to follow the refuge recommendation. The next generation of $B t$ soybean will continue to use Cry1Ac protein, now pyramided with Cry1A.105 and Cry2Ab2 ${ }^{51}$. Therefore, the implementation of resistance management strategies is essential for the sustainability of both current and new $B t$ soybean varieties for managing lepidopteran pests in South America. 


\section{Non-Bt soybean}

A. gemmatalis

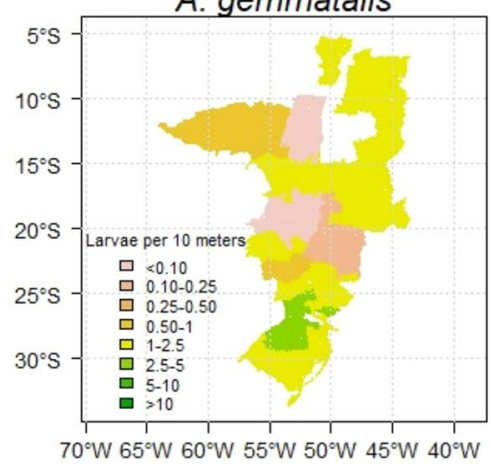

C. virescens

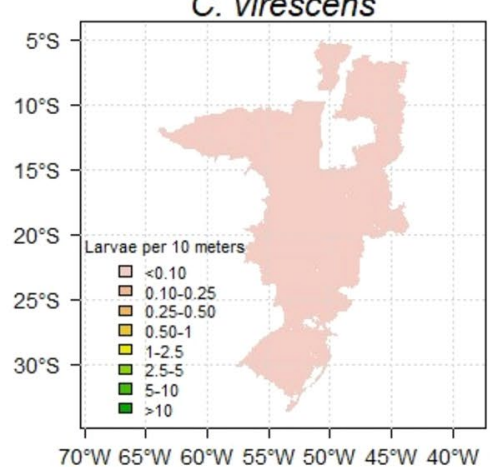

C. aporema

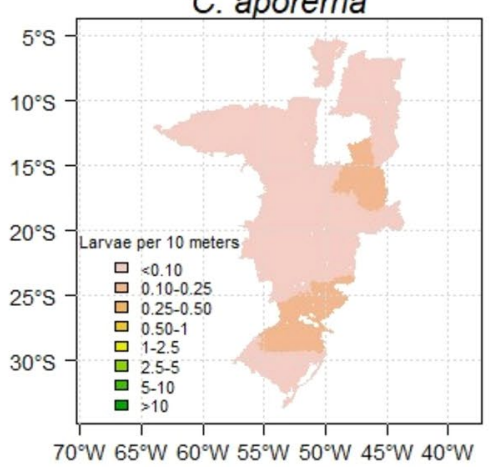

Helicoverpa spp.

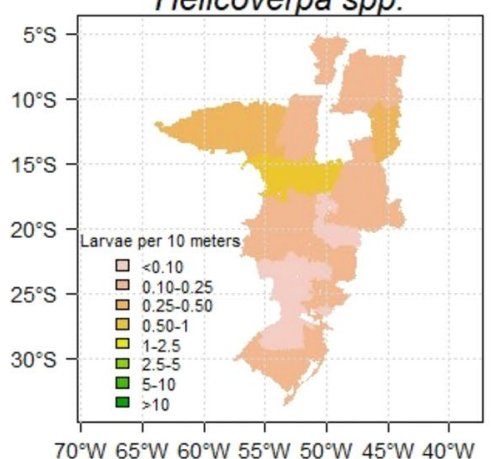

C. includens

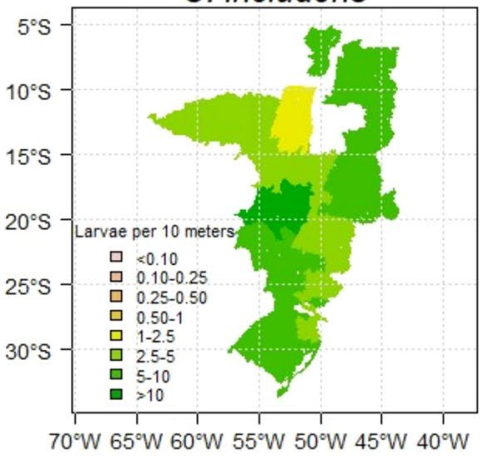

R. nu

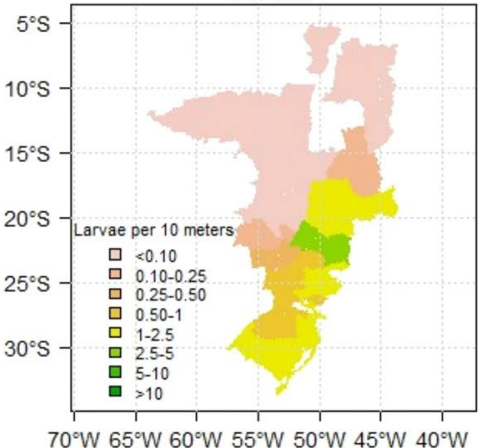

MON $87701 \times$ MON 89788 soybean

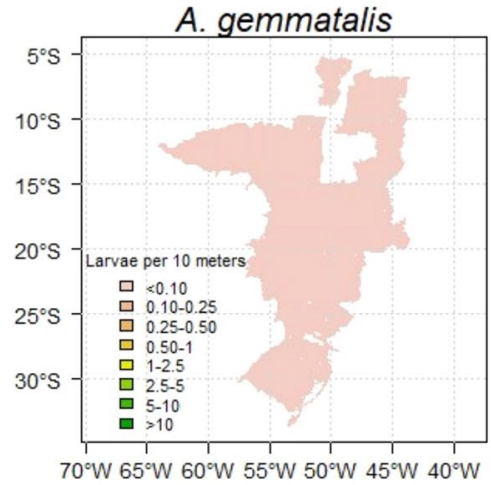

C. virescens

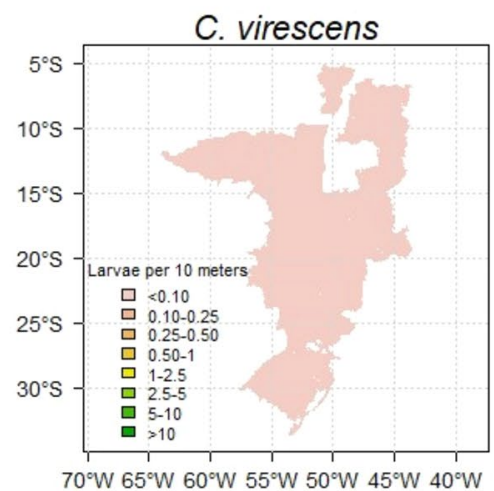

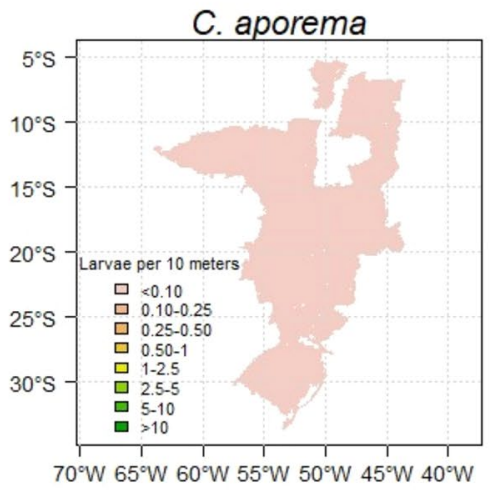
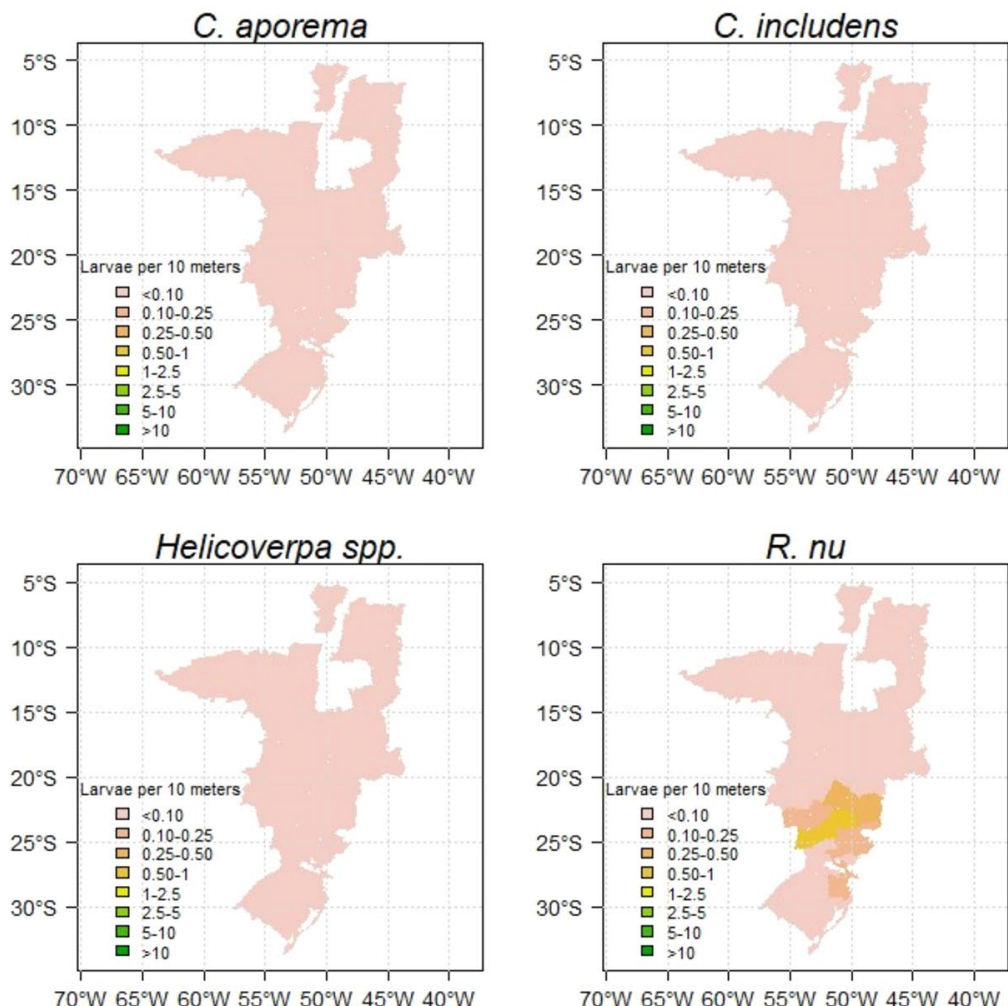

R. nu

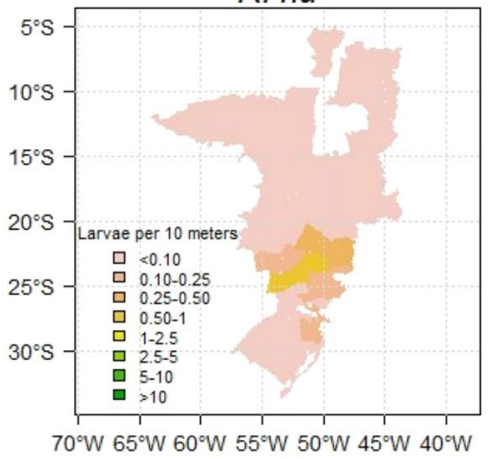


4Figure 5. Incidence of lepidopteran pests in MON $87701 \times$ MON 89788 soybean and non-Bt soybean in Brazilian fields sampled during the 2020/21 cropping season. A random effects statistical model was used to estimate pest abundance for each edaphoclimatic region. Separate analyses were conducted for each pest and field type. Pest abundance estimates were summarized using choropleth maps, where each edaphoclimatic region is color-coded according to its estimated pest abundance (different colors are assigned for estimates in the ranges $<0.10,0.1-0.25,0.25-0.5,0.5-1,1-2.5,2.5-5,5-10$, and $>10$ larvae/ $10 \mathrm{~m}$ ). In all maps that show more than one color, there is statistically significant variation across edaphoclimatic regions $(\mathrm{p}<0.05)$. Maps were generated using R statistical software-R version 4.0.2 (https://www.R-project.org/).

A

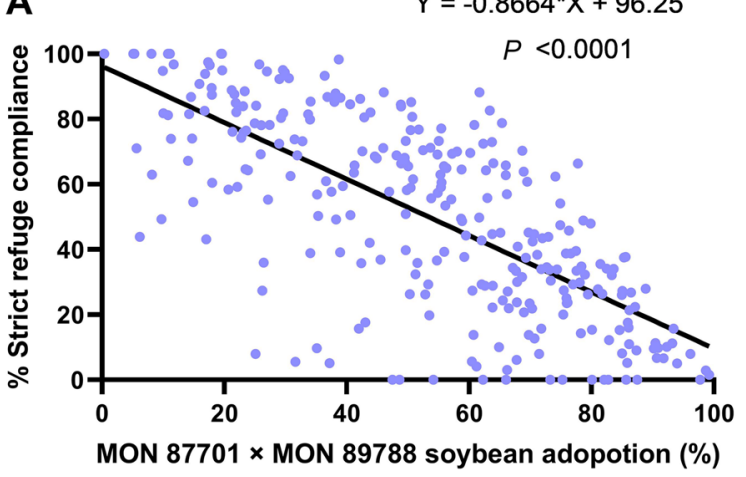

B

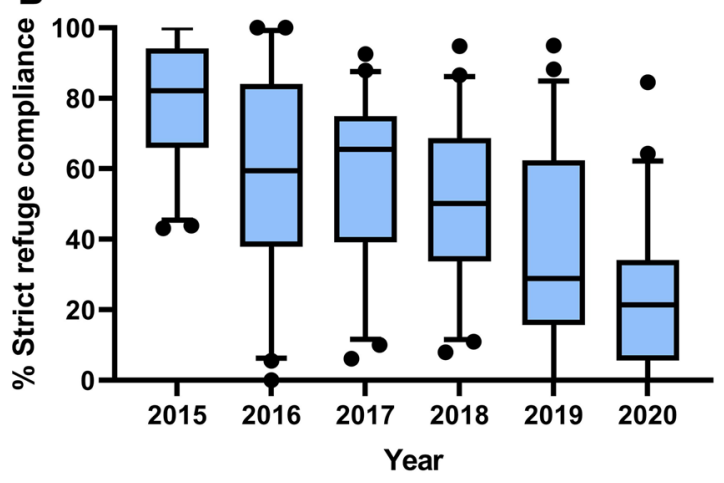

Figure 6. Relationship between adherence to structured refuge requirements and the adoption of MON $87701 \times$ MON 89788 soybean across mesoregions (A) and crop seasons (B) in Brazil. Data on MON $87701 \times$ MON 89788 soybean adoption and strict refuge compliance across mesoregions for the 2014/15 to $2019 / 20$ cropping seasons were obtained from market research companies Kynetec (2014/15-2017/18) and Spark (2018/19-2019/20). The middle horizontal line within each box in (B) represents the median; the bottom and top edges of the boxes represent the 25 th and 75 th percentiles, respectively.

Received: 13 August 2021; Accepted: 18 October 2021

Published online: 29 October 2021

\section{References}

1. Macrae, T. C. et al. Laboratory and field evaluations of transgenic soybean exhibiting high-dose expression of a synthetic Bacillus thuringiensis cry1A gene for control of Lepidoptera. J. Econ. Entomol. 98, 577-587 (2005).

2. Miklos, J. A. et al. Characterization of soybean exhibiting high expression of a synthetic Bacillus thuringiensis cry1A transgene that confers a high degree of resistance to lepidopteran pests. Crop Sci. 47, 148-157 (2007).

3. Spark. BIP soja 2021. Spark Smarter Decisions, Valinhos, SP. http://spark-ie.com.br (2021).

4. Bernardi, O. et al. Assessment of the high dose concept and level of control provided by MON $87701 \times$ MON 89788 soybean against Anticarsia gemmatalis and Pseudoplusia includens (Lepidoptera: Noctuidae) in Brazil. Pest Manag. Sci. 68, 1083-1091 (2012).

5. Bernardi, O. et al. High levels of biological activity of CrylAc protein expressed on MON $87701 \times$ MON 89788 soybean against Heliothis virescens (Lepidoptera: Noctuidae). Pest Manag. Sci. 70, 588-594 (2014).

6. Dourado, P. M. et al. High susceptibility to Cry1 Ac and low resistance allele frequency reduce the risk of resistance of Helicoverpa armigera to Bt soybean in Brazil. PLoS ONE 11, e0161388 (2016).

7. Horikoshi, R. J. et al. Large-scale assessment of lepidopteran soybean pests and efficacy of CrylAc soybean in Brazil. Sci. Rep. 11, 15956 (2021).

8. Gould, F. Sustainability of transgenic insecticidal cultivars: integrating pest genetics and ecology. Annu. Rev. Entomol. 43, 701-726 (1998).

9. Tabashnik, B. E., Van Rensburg, J. B. J. \& Carrière, Y. Field-evolved insect resistance to Bt crops: Definition, theory and data. J. Econ. Entomol. 102, 2011-2025 (2009).

10. Yano, S. A. et al. High susceptibility and low resistance allele frequency of Chrysodeixis includens (Lepidoptera: Noctuidae) field populations to Cry1Ac in Brazil. Pest Manag. Sci. 72, 1578-1584 (2015).

11. Tabashnik, B. E. \& Carrière, Y. Surge in insect resistance to transgenic crops and prospects for sustainability. Nat. Biotechnol. 35, 926-935 (2017).

12. CTNBio- Comissão Técnica Nacional de Biossegurança. Technical Opinion No. 2542/2010-Commercial release of genetically modified insect-resistant and herbicide-tolerant soy containing genetically modified events MON 87701 and MON 89788. http://ctnbio. mctic.gov.br/en/liberacao-comercial\#/liberacao-comercial/consultar-processo (2010).

13. Van Rensburg, J. B. J. First report of field resistance by stem borer, Busseola fusca (Fuller) to Bt-transgenic maize. S. Afr. J. Plant Soil 24, 147-151 (2007).

14. Storer, N. P. et al. Discovery and characterization of field resistance to Bt maize: Spodoptera frugiperda (Lepidoptera: Noctuidae) in Puerto Rico. J. Econ. Entomol. 103, 1031-1038 (2010).

15. Dhurua, S. \& Gujar, G. T. Field-evolved resistance to Bt toxin CrylAc in the pink bollworm, Pectinophora gossypiella (Saunders) (Lepidoptera: Gelechiidae), from India. Pest Manag. Sci. 67, 898-903 (2011).

16. Gassmann, A. J., Petzold-Maxwell, J. L., Keweshan, R. S. \& Dunbar, M. W. Field-evolved resistance to Bt maize by western corn rootworm. PLoS ONE 6, e22629 (2011).

17. Farias, J. R. et al. Field-evolved resistance to Cry1F maize by Spodoptera frugiperda (Lepidoptera: Noctuidae) in Brazil. Crop Prot. 64, 150-158 (2014). 
18. Bernardi, D. et al. Cross-resistance between Cryl proteins in fall armyworm (Spodoptera frugiperda) may affect the durability of current pyramided Bt maize hybrids in Brazil. PLoS ONE 10, e0140130 (2015).

19. Mohan, K. S., Ravi, K. C., Suresh, P. J., Sumerford, D. \& Head, G. P. Field resistance to the Bacillus thuringiensis protein Cryl Ac expressed in Bollgard hybrid cotton in pink bollworm, Pectinophora gossypiella (Saunders), populations in India. Pest Manag. Sci. 72, 738-746 (2016).

20. Omoto, C. O. et al. Field-evolved resistance to Cryl Ab maize by Spodoptera frugiperda in Brazil. Pest Manag. Sci. 72, 1727-1736 (2016).

21. Naik, V. C., Kumbhare, S., Kranthi, S., Satija, U. \& Kranthi, K. R. Field-evolved resistance of pink bollworm, Pectinophora gossypiella (Saunders) (Lepidoptera: Gelechiidae), to transgenic Bacillus thuringiensis (Bt) cotton expressing crystal 1Ac (CrylAc) and Cry2Ab in India. Pest Manag. Sci. 74, 2544-2554 (2018).

22. Sanchez, N. E. \& Pereyra, P. C. Life tables of the soybean looper Rachiplusia nu (Lepidoptera: Noctuidae) in the laboratory. Rev. Soc. Entomol. Arg. 54, 89-96 (1995).

23. Sánchez, N. E., Pereyra, P. C. \& Gentile, M. V. Population parameters of Epinotia aporema (Lepidoptera: Tortricidae) on soybean. Rev. Soc. Entomol. Arg. 56, 151-153 (1997).

24. Barrionuevo, M. J., Murúa, M. G., Goane, L., Meagher, R. \& Navarro, F. Life table studies of Rachiplusia nu (Guenée) and Chrysodeixis (= Pseudoplusia) includens (Walker) (Lepidoptera: Noctuidae) on artificial diet. Fla. Entomol. 95, 944-951 (2012).

25. Ferreira, B. S. C. Sampling Epinotia aporema on Soybean in Sampling Methods in Soybean Entomology (eds. Kogan, M. \& Herzog, D. C) 374-381 (Springer 1980).

26. Specht, A. et al. Biotic potential and life tables of Chrysodeixis includens (Lepidoptera: Noctuidae), Rachiplusia nu, and Trichoplusia ni on soybean and forage turnip. J. Insect Sci. 19, 1-8 (2019).

27. Santos, S. R. D., Specht, A., Carneiro, E. \& Casagrande, M. M. The influence of agricultural occupation and climate on the spatial distribution of Plusiinae (Lepidoptera: Noctuidae) on a latitudinal gradient in Brazil. Rev. Bras. Entomol. 65, e20200103 (2021).

28. Greene, G. L., Leppla, N. C. \& Dickerson, W. A. Velvetbean caterpillar: A rearing procedure and artificial medium. J. Econ. Entomol. 69, 487-488 (1976).

29. Andow, D. A. \& Alstad, D. N. F 2 screen for rare resistance alleles. J. Econ. Entomol. 91, 572-578 (1998).

30. Andow, D. A. \& Alstad, D. N. Credibility interval for rare resistance allele frequencies. J. Econ. Entomol. 92, 755-758 (1999).

31. R Core Team. R: A Language and Environment for Statistical Computing. (R Foundation for Statistical Computing, 2020). https:// www.R-project.org/.

32. Herzog, D. C. Sampling soybean looper on soybean. In Sampling Methods in Soybean Entomology (eds. Koogan, M. \& Herzog, D. C.) 141-168 (Springer, 1980).

33. Navarrro, F. R., Saini, E. D. \& Leiva, P. D. Clave pictórica de polillas de interés agrícola. INTA, EEA PERGAMINO, Pergamino, Buenos Aires, Argentina (2009).

34. Gilligan, T. M. \& Passoa, S. C. LepIntercept-An identification resource for intercepted Lepidoptera larvae. (Identification Technology Program (ITP), 2014). http://idtools.org/id/leps/lepintercept/key.html (2014).

35. Chen, D. et al. Bacillus thuringiensis chimeric proteins Cry1A. 2 and Cry1B. 2 to control soybean lepidopteran pests: New domain combinations enhance insecticidal spectrum of activity and novel receptor contributions. PLoS ONE 16, e0249150 (2021).

36. SAS Institute Inc., SAS/STAT: 9.1. Statistical Analysis System: getting started with the SAS learning. SAS Institute, Cary, NC (2002).

37. Farias, J. R. B., Nepomuceno, A. L., Neumaier, N. Ecofisiologia da soja. Londrina: Embrapa-Centro Nacional de Pesquisa de Soja, Circular Técnica, 48 (2007).

38. Sosa-Gómez, D. R. et al. Manual de Identificação de Insetos e Outros Invertebrados da Cultura da Soja. (Embrapa Soja-Documentos (INFOTECA-E), 2014).

39. Kaster, M. \& Farias, J. R. B. Regionalização dos Testes de Valor de Cultivo e Uso e da indicação de Cultivares de Soja-terceira Aproximação (Embrapa Soja-Documentos (INFOTECA-E), 2012).

40. IBGE. Divisão Regional do Brasil em Mesorregiões e Microrregiões Geográficas. v. 1. (IBGE, 1990).

41. GraphPad Prism. GraphPad Prism version 8.1.2 for Windows, GraphPad Software, San Diego. www.graphpad.com.

42. Huang, F., Parker, R., Leonard, R., Yong, Y. \& Liu, J. Frequency of resistance alleles to Bacillus thuringiensis-corn in Texas populations of the sugarcane borer, Diatraea saccharalis (F.) (Lepidoptera: Crambidae). Crop Prot. 28, 174-180 (2009).

43. Rodrigues-Silva, N. et al. Negative cross-resistance between structurally different Bacillus thuringiensis toxins may favor resistance management of soybean looper in transgenic Bt cultivars. Sci. Rep. 9, 1-9 (2019).

44. Yano, S. A. C. et al. Tolerância de Anticarsia gemmatalis Hübner, Pseudoplusia includens (Walker) e Rachiplusia nu (Guenée) à proteína Cry1Ac. In: Embrapa Soja-Artigo em anais de congresso (ALICE). (Embrapa, 2012).

45. Perini, C. R. et al. Genetic structure of two Plusiinae species suggests recent expansion of Chrysodeixis includens in the American continent. Agric. For. Entomol. 23, 250-260 (2020).

46. Bueno, A. F. et al. Challenges for adoption of integrated pest management (IPM): The soybean example. Neotrop. Entomol. 50, 5-20 (2021).

47. Carrière, Y. et al. Governing evolution: A socio-ecological comparison of resistance management for insecticidal transgenic Bt crops among four countries. Ambio 49, 1-16 (2020).

48. Heinrichs, E. A. \& Silva, R. F. P. Estudo de níveis de população de Anticarsia gemmatalis Hubner, 1818 e Plusia sp. em soja no Rio Grande do Sul. Agron. Sulriograndense 11, 29-35 (1975).

49. Guedes, J. V. C. Lagartas da soja: das lições do passado ao manejo do futuro. Rev. Plantio Direto 144, 10-22 (2015).

50. Silva, C. S. et al. Population expansion and genomic adaptation to agricultural environments of the soybean looper, Chrysodeixis includens. Evol. Appl. 13, 2071-2085 (2020).

51. Bacalhau, F. B. et al. Performance of genetically modified soybean expressing the Cry1A. 105, Cry2Ab2, and Cry1 Ac proteins against key Lepidopteran pests in Brazil. J. Econ. Entomol. 113, 2883-2889 (2020).

\section{Acknowledgements}

We thank the Coordenação de Aperfeiçoamento de Pessoal de Nível Superior-Brasil (CAPES) (Finance Code 001) and scholarships provided by Conselho Nacional de Desenvolvimento Científico e Tecnológico (CNPq) to O.B. (Process \# 305464/2020-5), D.R.S.G. (Process \# 305398/2018), A.F.B. (Process \# 142340/2018-9), C.O. (Process \# 312086/2013-0) and A.S.C. (Process \# 311465/2018-8). We also thank Fundação de Amparo à Pesquisa do Estado do Rio Grande do Sul (FAPERGS) (Grant number 19/2551-0002289-1) and Fundação de Amparo à Pesquisa do Estado de São Paulo (FAPESP) (Grant number 2019/18282-9) for partial financial support to O.B. and C.O., respectively.

\section{Author contributions}

All authors conceived and designed the experiments; R.J.H., O.B., D.N.G., A.A.S., G.O.C., D.S.F., A.S.C and P.M.D. collected data; R.J.H., O.B., A.W., S.M., A.S.C., P.M.D, and G.H. performed the statistical analysis, R.J.H., 
O.B., D.N.G., A.A.S., A.W., G.O.C., E.R., D.S.F., D.R.S.G., A.F.B., C.O., G.U.B., A.S.C., S.M., P.M.D., and G.H. interpreted the results and wrote the manuscript. All authors read and approved the final manuscript.

\section{Competing interests}

R.J.H., A.A.S., A.W., G.O.C., G.U.B., S.M., P.M.D. and G.H. are employed by Bayer Crop Science. This research was partially financed by Bayer Crop Science. The authors declare no additional conflicts of interest. O.B., D.N.G., E.R., D.S.F., D.R.S.G., A.F.B., C.O. and A.S.C. declare no potential conflict of interest.

\section{Additional information}

Supplementary Information The online version contains supplementary material available at https://doi.org/ 10.1038/s41598-021-00770-0.

Correspondence and requests for materials should be addressed to R.J.H.

Reprints and permissions information is available at www.nature.com/reprints.

Publisher's note Springer Nature remains neutral with regard to jurisdictional claims in published maps and institutional affiliations.

(c) (1) Open Access This article is licensed under a Creative Commons Attribution 4.0 International cc) License, which permits use, sharing, adaptation, distribution and reproduction in any medium or format, as long as you give appropriate credit to the original author(s) and the source, provide a link to the Creative Commons licence, and indicate if changes were made. The images or other third party material in this article are included in the article's Creative Commons licence, unless indicated otherwise in a credit line to the material. If material is not included in the article's Creative Commons licence and your intended use is not permitted by statutory regulation or exceeds the permitted use, you will need to obtain permission directly from the copyright holder. To view a copy of this licence, visit http://creativecommons.org/licenses/by/4.0/.

(C) The Author(s) 2021 